\title{
Low field NMR surface relaxivity studies of chalk and argillaceous sandstones
}

\author{
Katika, Konstantina; Fordsmand, H.; Fabricius, Ida Lykke
}

Published in:

13th International Bologna Conference on Magnetic Resonance in Porous Media

Publication date:

2016

Document Version

Peer reviewed version

Link back to DTU Orbit

Citation (APA):

Katika, K., Fordsmand, H., \& Fabricius, I. L. (2016). Low field NMR surface relaxivity studies of chalk and argillaceous sandstones. In 13th International Bologna Conference on Magnetic Resonance in Porous Media: Book of Abstracts [028]

\section{General rights}

Copyright and moral rights for the publications made accessible in the public portal are retained by the authors and/or other copyright owners and it is a condition of accessing publications that users recognise and abide by the legal requirements associated with these rights.

- Users may download and print one copy of any publication from the public portal for the purpose of private study or research.

- You may not further distribute the material or use it for any profit-making activity or commercial gain

- You may freely distribute the URL identifying the publication in the public portal

If you believe that this document breaches copyright please contact us providing details, and we will remove access to the work immediately and investigate your claim 


\section{Low field NMR surface relaxivity studies of chalk and argillaceous sandstones}

K. Katika ${ }^{\mathrm{a}}$ H. Fordsmand ${ }^{\mathrm{b}}$, I.L. Fabricius ${ }^{\mathrm{a}}$

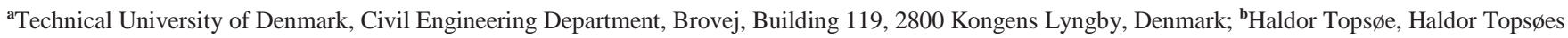
Allé 1, 2800 Kongens Lyngby, Denmark.

This paper provides an insight into how the surface relaxivity of minerals constituting rocks are affected by changes in temperature and Larmor frequency. This is relevant for connecting conventional rock core testing data to reservoir logging data.

In the present study, we perform laboratory NMR $T_{2}$ measurements on Gorm field chalk, Stevns Chalk, Solsort field greensand and Berea sandstone so as to determine the surface relaxivity, $\rho$, of the rock forming minerals. Transverse relaxation rate, $1 / T_{2}$ is proportional to $\rho$ and the surface-to-volume ratio $(S / V)$ of the pore space [1]:

$$
\frac{1}{T_{2}}=\rho_{2} \frac{\mathrm{s}}{V}
$$

Paramagnetic minerals in contact with the water accelerate the surface transverse relaxation (equation 1) at higher frequencies, so $T_{2}$ distributions at Lamor frequency 2 and $20 \mathrm{MHz}$ at $40^{\circ} \mathrm{C}$ were used to identify the presence of paramagnetic minerals in water saturated rocks. Therefore, the surface relaxivity of the respectively purely calcitic and purely quartzitic Stevns chalk and Berea sandstone proved not to be affected by the changes in frequency. By contrast, paramagnetic minerals in the Gorm field chalk and Solsort field greensand resulted in higher values of $\rho$ when the NMR measurements were performed at higher Larmor frequency (Figure 1).

$T_{2}$ distributions at temperatures ranging from 10 to $70^{\circ} \mathrm{C}$ provide a valuable connection between lab and field transverse relaxation measurements. The $T_{2}$ distributions illustrate that $\rho$ for calcite tends to decrease with temperature whereas $\rho$ for quartz tends to increase with temperature. These changes may be used to describe changes in the porosity and pore size distribution obtained in the lab, compared to those in the logs.

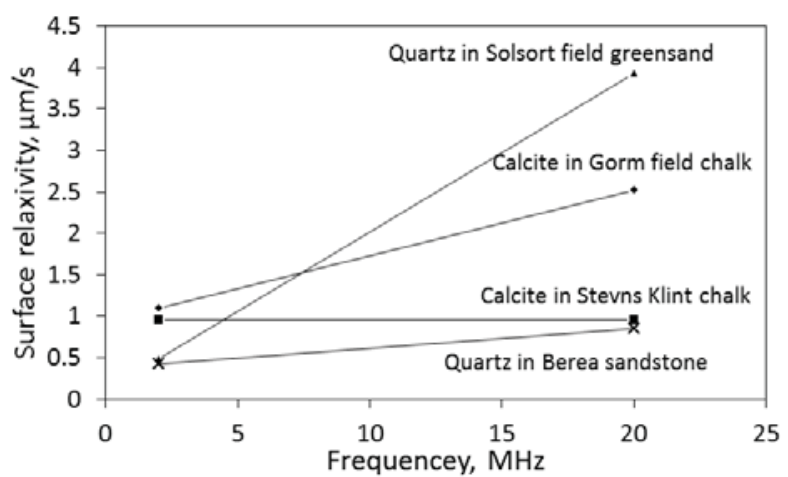

Figure 1 - Changes in the surface relaxivity of the main minerals constituting the rocks under investigation versus the Larmor frequency of the measurements. The $T_{2}$ value was acquired at 2 and $20 \mathrm{MHz}$ at $40^{\circ} \mathrm{C}$.
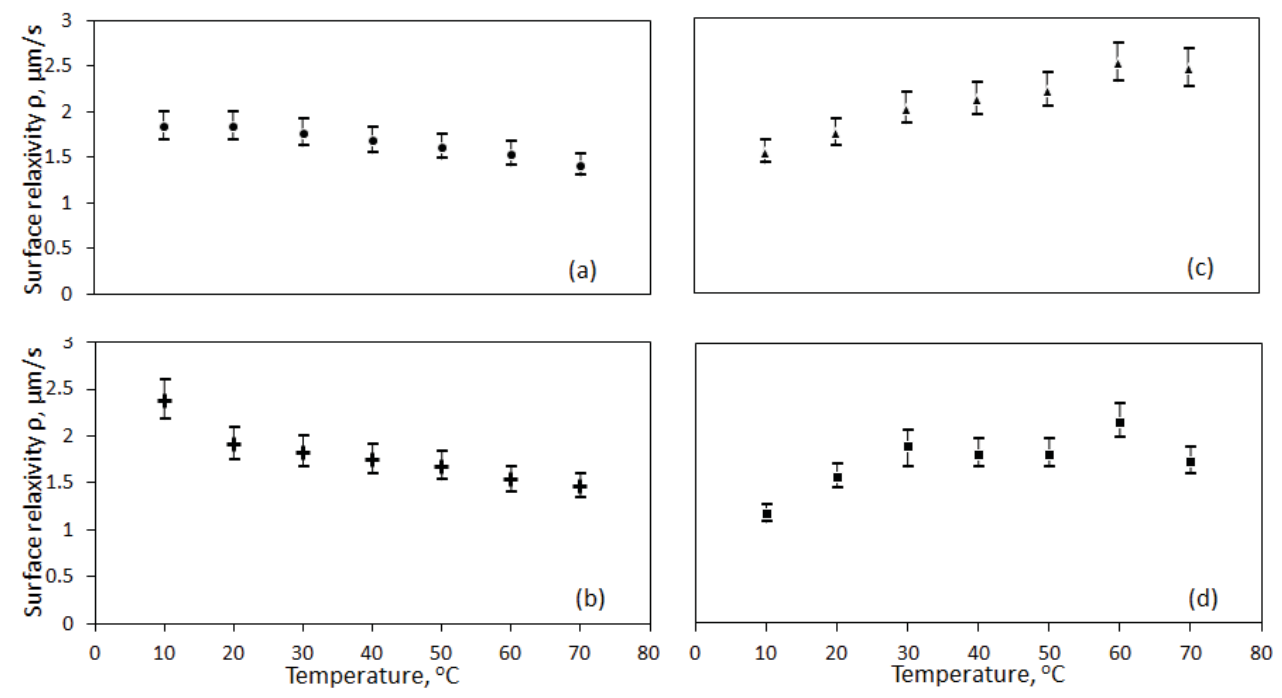

Figure 2 - The surface relaxivity of calcite in (a) Gorm field chalk and (b) Stevns Klint chalk, quartz in (c) Solsort field greensand and (d) Berea sandstone at $20 \mathrm{MHz}$ obtained at temperatures ranging from 10 to $70^{\circ} \mathrm{C}$.

\section{References}

[1] Dunn, K., Bergman, D.J., and LaTorraca, G.A., 2002, Nuclear Magnetic Resonance-Petrophysical and Logging Applications. New York: Handbook of Geophysical Exploration: Seismic Exploration, Pergamon Press. 